\title{
Human Capacity and Procurement Performance at Two Tertiary Institutions in Uganda
}

\author{
Epiphany Odubuker Picho ${ }^{1}$ \\ ${ }^{1}$ Muni University [Email: epipicho@gmail.com]
}

\begin{abstract}
This study aimed at establishing the ways in which institutional human capacity affects performance in public procurement at Uganda College of Commerce (UCC), Pakwach and National Teachers College (NTC), Muni, both located in West Nile sub-region of Uganda. The study followed a cross-sectional survey design. Both quantitative and qualitative approaches were used. This study targeted a random sample of 122 respondents. Purposive sampling was also used to select the Accounting Officers and the Contracts Committee members of the institutions. The findings revealed a positive correlation (.611) between institutional human capacity and procurement performance. Thus, it was concluded that institutional human capacity (measured in terms of professionalism and competence) affected performance in institutions in the region. Therefore, prioritisation of institutional human capacity building is recommended.
\end{abstract}

Keywords: Procurement; Capacity building; Financial management.

\section{$1 \quad$ Introduction}

Historically, the first known procurement order dates back to between 2800 and $2400 \mathrm{BC}$. The order was for " 50 jars of fragrant smooth oil for 600 small weight in grain" (Coe, 1989, p. 87). Other evidence of historical procurement includes the development of the silk trade between China and a Greek colony in 800 BC. In the United States, according to Page (1980) as cited in Scott (2008), government procurement at the municipal level predates that of state and federal governments. In the settlements and colonies, printing was one of a few services contracted out by government. However, there were no professional procurement officials - the practice of procurement being older than the discipline. Goods and services needed by government were supplied by commissioners or commissaries who received a commission on what they 
bought for the militia or other administrative units. It was not until the late 1800 s that state legislatures began to create boards or bureaus responsible for purchasing, but central purchasing was hardly a practice at that time. In 1810, Oklahoma was the first state government to create a board to procure centrally for all state departments and agencies (Page, 1980). Many local governments soon followed Oklahoma's example, according to Arthur Thomas (1919) as cited in Scott (2008).

Since then, centralized purchasing has gradually become common in state and local governments. However, the centralization trend has been challenged in recent years. Many practitioners and researchers have contended that purchasing authority, especially in government, must be decentralized in order to provide support that is more responsive to end users, eliminate bureaucratic obstacles to programme accomplishment, improve inter-departmental coordination, and empower service delivery managers to procure what they need without impediment by a centralized organization.

In addition to centralized purchasing, there was movement toward adopting a uniform government procurement code. The American Law Institute and the National Conference of Commissioners on Uniform State Laws, with the endorsement of the American Bar Association, promulgated the "Uniform Commercial Code" (UCC) and completed it in the fall of 1951. Pennsylvania was the first state to enact the UCC; and by 1980, all states except Louisiana had adopted most provisions of the Uniform Code (Page, 1980). In 1979, the American Bar Association (ABA) issued The Model Procurement Code "after five years of intensive effort directed by a Coordinating Committee on a Model Procurement Code" (American Bar Association, 2000, p. 101). In 2000, the ABA updated this publication and issued The 2000 Model Procurement Code for States and Local Governments.

At the federal level, the first purchasing action occurred in 1778 when the Continental Congress approved the appointment of purchasing commissionaires, whose purchasing work was compensated by two percent of the value of their disbursements in support of the Continental army. However, by the end of the year, as this arrangement led to excessive costs and possibilities of fraud, the purchasing officers were placed on salary. In 1792, the US Congress passed a purchasing-related Act that authorized the departments of War and Treasury to make purchases in the name of the United States. The first significant procurement, made in 1794, was for a group of six large frigates for the new US Navy. However, bad early experiences with this procurement procedure led to the 1795 passage of the first comprehensive procurement legislation, the Purveyor of Public Supplies Act, which became the basis for military procurement. Misconduct and abuses in federal procurement again led to an Act Concerning Public Contracts of 1808, prohibiting members of Congress from benefiting from government contracts 
and the Procurement Act of 1809, requiring competition in government procurement. Since then, a series of legislations and executive orders were passed or issued.

Currently, there are 50 states and over 83,000 local procurement entities and as each governmental unit enjoys its autonomy, it is impossible, as space would not be enough, to document various procurement laws and regulations in this article. In 1975, in a pioneering effort, the Council of State Governments published a report tabulating purchasing statutes and regulations of all states, major counties and cities.

Despite many government procurement reform efforts having been undertaken, it seems that all the public procurement problems that were prevalent over eighty years ago are still afflicting the profession today, and will persist. Managing procurements in the public sector has emerged as one of the most daunting challenges facing public managers. Given the importance of public sector procurement, more robust application of theoretical perspectives and empirical research of organizations at the operational level is greatly needed (Brown, Potowski \& Van Slyke, 2006). This study takes a step by examining the institutional human capacity and public procurement performance through the lens of institutional theory (Scott, 2008).

This study was guided by institutional theory to explain how institutional dynamics affect public procurement performance in tertiary institutions in the West Nile Sub-Region in Uganda. Institutional theory attempts to describe the deeper and more resilient aspects of how institutions are created, maintained, changed and dissolved (Scott, 2005; Scott, 2008), and deals with the pervasive influence of institutions on human behaviour including the processes by which structures such as rules, routines and norms guide social behaviour.

Institutional theory is the traditional approach that is used to examine elements of public procurement (Obanda, 2010). There is no single and universally agreed definition of "institution" or "institutional theory". According to Scott (2004), institutions are composed of cultural-cognitive and regulative elements that, together with associated activities and resources, give meaning to life. Scott explains the three pillars of institutions as regulatory, normative and cultural-cognitive. The regulatory pillar emphasizes the use of rules, laws and sanctions as enforcement mechanism, with expedience as the basis for compliance. The normative pillar refers to norms (how things should be done) and values (the preferred or desirable), which are the social obligations, being the basis of compliance. The cultural-cognitive pillar rests on shared understanding (common beliefs, symbols).

Institutional theory highlights the importance of the wider institutional environment as the ground in which organizations are rooted (Scott, 2005). The key idea behind institutionalization is that much organizational action reflects a pattern of doing things that evolves over time and becomes legitimated within 
an organization and an environment (Pfeffer, as cited in Eyaa \& Oluka, 2011). Institutional theory (Scott, 2001) can be used to explain the problem of managing government procurement, conceptualized as the "smart buyer problem" by Kettl (1993). Kettl argued that, while embracing the market-based promises of procurement, governments have failed to develop the capacity to address even the most fundamental procurement questions, such as what to buy, who to buy from and what has to be bought. He suggests that the problem is partly attributable to institutional barriers in government agencies that prevent them from becoming learning organizations. This study explores the proposition that institutional dynamics within procuring organizations may contribute to this problem. Government institutions do not behave as a single buyer with clearly defined buying objectives. Multiple organizations, each shaped by institutional factors, lay claim to processes relating to Kettl's smart buyer questions. As key organizational participants become aligned with their own regulative, normative, and socio-cognitive institutional "pillars," smart buying behaviour may become confounded by institutional factors and constraining organizational structures. For this study, an organizational field consisting of the programme office, procurement office, and budget office will be selected as the level of analysis. Both quantitative and qualitative approaches will be developed to analyse data from public sources, including public institution policy documents, audit reports, and other published information. Data from auto-ethnographic accounts, interviews, content analyses and the case studies will help frame the institutional characteristics of these offices in public institutions.

Public procurement is the acquisition of goods, services and works by a procuring entity using public funds (World Bank, 1995). It is the process by which government departments or agencies purchase goods and services from the private sector. Public procurement as a function of government includes decisions about the services that will be delivered to local authorities and the communities they serve (Hughes, 2005). It is utilized not only to secure goods and services required by public sector organizations for their missions and to support services provided to taxpayers, but also used to implement national policies and to achieve social and other objectives (Thai, 2005). Depending on local laws, the relevant government officials will have to follow a set system for procurement. This system could cover the way they advertise for suppliers, the grounds on which they choose a supplier, and the way in which they measure and enforce the requirements they put on the supplier. The usual aims of such a system will be to take advantage of competition between suppliers and to reduce the risk of corruption.

Institutional human capacity often implies a broader focus of empowerment of social capital (Segnestam et al, 2002). It refers to the skills, competences and abilities of people and communities in institutions necessary to achieve set 
goals. Human capacity is the stock of knowledge, habits, social and personality attributes, including creativity, embodied in the ability to perform labour to produce economic value (Becker, 1994). Alternatively, human capacity is a collection of resources - all the knowledge, talents, skills, abilities, experience, intelligence, training, judgement, and wisdom - possessed individually and collectively by individuals in a population (Abel \& Deitz, 2012). These resources are the total capacity of the people that represents a form of wealth which can be directed to accomplish the goals of the institution. In this study, institutional human capacity was taken to refer to the professionalism and competence of human resources.

According to Van Weele (2006), procurement performance is considered the result of two elements: procurement effectiveness and procurement efficiency. Performance provides the basis for an organization to assess how well it is progressing towards its predetermined objectives, identifies areas of strengths and weaknesses and decides on future initiatives with the goal of how to initiate performance improvements. This means that procurement performance is not an end in itself but a means to effective and efficient control and monitoring of the procurement function (Lardenoije, Van Raaij \& Van Weele, 2005). Procurement efficiency and procurement effectiveness represent different competences and capabilities for the procurement function. CIPS Australia (2005) presents the differences between efficiency and effectiveness. Efficiency reflects that the organization is "doing things right" whereas effectiveness relates to the organization "doing the right thing". This means an organization can be effective and fail to be efficient, the challenge being to balance between the two. In this study, procurement performance was measured using Van Weele's (2006) definitions of procurement efficiency and procurement effectiveness.

Public Procurement has always been a big part of the developing countries' economies, accounting for an estimated $9-13 \%$ of the developing nations' Gross Domestic Product (GDP); and it is, therefore, an area that needs attention in the face of increasing non-compliance (Odhiambo \& Kamau, 2003). Procurement managers and stakeholders in the Public Service serve institutions created and governed by a complex array of statutes, regulations, policies and directives. They operate in an environment of increasingly intense scrutiny and accelerated changes driven by technology, programme reviews, and public and political expectations for service improvements. When combined, these result into growing institutional complexity and risks. However, Ntayi (2009) observes that millions of dollars get wasted due to inefficient and ineffective procurement structures, policies and procedures as well as failure to impose sanctions for violation of procurement rules, thus resulting in poor service delivery. The level of compliance to procurement regulations can determine whether a public institution meets its goals and objectives or not. 
In order to improve the management of public procurement, many countries have come up with procurement reforms. According to Arrowsmith and Trybus (2003), the last decade of the twentieth century has witnessed the start of the global evolution in public procurement. Nonetheless, Thai (2005) asserts that challenges in public procurement go beyond procurement regulations to include procurement process, methods, organizational structure and work force.

This assertion is supported by the African Peer Review Mechanism Country Review (APRM) Report on Uganda (2009), which asserts that non-compliance with the regulations is so high in Uganda. The same report estimates that more than UGX. 30 billion (US Dollars 184) is lost every year due to noncompliance. De Boer and Telgen (1998), as cited by Gelderman et al (2006), explain that compliance is a problem not only in the third world countries but also evident in the European Union countries. Gelderman et al (2006) further advances reasons for non-compliance as explained by the tendency to avoid red tape involved in the procurement process.

In Uganda, the need for procurement reforms became urgent because of internal and external pressure given the fact that the Government, hence, the taxpayer, was losing huge sums of money in poorly managed procurement processes. The procurement reforms that were recommended in 2001 in Uganda in the Country Procurement Assessment Report are: the abolition of the Central Tender Board; enactment of a Procurement Law (Public Procurement and Disposal of Assets Act); establishment of a policy regulation body, the Public Procurement and Disposal of Assets Authority; establishment of Contract Committees and Procurement Units in procuring entities; harmonization of central and local government regulations; incorporation of procurement plans in sector investment programmes; preparation of standard bidding documents, establishment of a procurement cadre in the civil service and restoration of professionalism in the procurement function. All procurements and disposals handled by public procuring and disposing entities (PDEs) are governed by the regulations in the PPDA Act (2003). These regulations specify procurement and disposal procedures that have to be followed by all persons involved in procurement and disposal processes in order to ensure fairness, transparency, competitiveness and non-discrimination to all potential providers of goods, services and works (PPDA Act, 2003). Local authorities and other government entities, such as parastatals, schools and universities, are by definition public entities. Currently, all procurements are undertaken by the public entities themselves, which has in turn created an extensive demand for high procurement performance in each public entity (Agaba \& Shipman, 2006).

Uganda's procurement regulations explicitly identify public universities as procurement entities. In these institutions, Accounting Officers are responsible for the procurement of goods, works and services. In public universities in 
Uganda, the University Secretary is the Accounting Officer responsible for the entity. Other players are the Contracts Committee, the Evaluation Committee (ad-hoc), Negotiation Committees (ad-hoc), Procurements and Disposal Units (PDUs) and the User Departments. All these play their independent roles to see to it that whatever is required, as planned, is procured in accordance with the PPDA Act to ensure value for money.

According to the Public Procurement and Disposal of Public Assets Authority (PPDA, 2009), in Makerere University, Standard Bidding documents were not used for procurements handled by the User Departments. As a result, specifications were in most cases not well defined. Bidding Forms issued by the Authority were not utilized. Use of PPDA forms avoids wrong submissions by the bidders and facilitates evaluations. Evaluation reports were in some cases not signed by all the evaluators; for example, one member did not sign the evaluation report for the extension of the Faculty of Economics and Management. Financial loss of UGX 56,032,960 was registered. The decision to award a tender to M/s Plasticom led to a cost increase of UGX 4,000 per chair, increasing the total by an extra UGX 6,444,000, which extra amount could have purchased 460 more chairs if the tender had been awarded to M/s Nice Plastics. From the records available, the team noted that M/s Copy Cat (Uganda) Ltd offered photocopier with superior options at UGX 22,950,000 than that offered by M/s Kazinga Channel at a higher price of UGX 26,356,775. The choice by the committee of a higher priced photocopier caused a financial loss of UGX 3,406,775.

In respect to Gulu University, the Public Procurement and Disposal of Public Assets Authority (2011) revealed that seven cases, representing 14\% of the cases, were contracted at sums that varied greatly from those indicated in the procurement plan for the year under review. The audit revealed that six cases, representing $12 \%$ of the sample, were not on the procurement plan for the FY 2010/2011. There was a decline in performance (FY 2010/11, the high risk plus medium risk was $96 \%$ by number and $99 \%$ by value compared with FY $2007 / 08$ at $77 \%$ by number and $81 \%$ by value). It was concluded that the entity's performance was very poor. Forty-nine cases, representing $99 \%$ by value, were in the high and medium risk categories. It was against this background that the researcher was interested in establishing how institutional human capacity affect performance in public procurement in tertiary institutions in the West Nile sub-region of Uganda.

The procurement function has become increasingly important over the past decades since purchasing and supply has become a major determinant of corporate success. Significant business pressure because of cost pressure and regulatory compliance has forced the procurement function to focus on cost reduction and attaining more value for money. The procurement function usually takes large amounts of organizations' revenue, hence it is becoming an 
expensive undertaking for many organizations (Chan \& Lee, 2003); and if not properly done it can lead to significant regret.

The inefficiency and incompetence of overall administration and management of the procurement function in Uganda's public universities contributes to loss of millions of Uganda shillings annually. According to Victor (2012), procurement expenditure could be minimized through implementation of effective procurement practices. The enactment of the Public Procurement and Disposal Act (PPDA Act) and the Regulations, as well as the establishment of a public procurement oversight authority were some of the reforms meant to promote efficiency, effectiveness, good performance and accountability in public procurement.

Regardless of the effort by the Uganda government to improve the performance of the procurement function, public procurement in government universities is still marred by poor procurement performance. Failure to implement or delayed implementation of recommended performance standards has resulted in unnecessarily high operation costs and uncoordinated business activities, thus affecting the function's performance (PPDA, 2007).

It is against this background that this study was conducted to establish the effect of institutional human capacity on performance of the procurement function at Uganda College of Commerce Pakwach and National Teachers' College, Muni, in Arua. These were selected because of complaints related to their procurement performance. The study concentrated on inter-institutional dynamics and their effect on procurement performance. Inter-institutional dynamics were restricted to aspects of institutional legal environment, institutional human capacity, institutional culture, institutional politics and institutional ethical values. Procurement performance was restricted to public procurement efficiency and effectiveness. The research focused on a period of five years, 2010 to 2015 , for obtaining information about inter-institutional dynamics and procurement performance.

\section{$2 \quad$ Related Literature}

Institutional theory deals with the processes by which structures (including schemes, rules, norms, and routines) become established as authoritative guidelines of social behaviour (Scott, as cited in Kenyakisa \& Kiruja, 2015). Different components of institutional theory explain how these elements are created, diffused, adopted, and adapted over time; and how they fall into decline and disuse. Institutional theory states that organizations exist in an institutional environment, which defines and delimits their reality (Scott, as cited in Kenyakisa \& Kiruja, 2015). 
Institutional theory describes the effects of external institutional pressures on organizations and defines institutions as regulatory structures, government agencies, laws, courts, and professions, as well as interest groups and public opinion (Lowell, as cited in Makabira, 2014). The rules and norms set out by the institutions in an environment are endorsed by various actors. When speaking of actors and institutional environment in this research, reference is made to the norms represented by the actors in the environment and the pressure that these norms exert on other actors in the environment. A strength attributed to institutional theory is its ability to explain non-choice behaviour of organizations, how they conform to norms without questioning them and undertaking public function (Lowell, as cited in Makabira, 2014).

Institutional theory adopts a sociological perspective to explain organizational structures and behaviour (Dunn \& Jones, 2010). It draws attention to the social and cultural factors that influence organizational decision-making and, in particular, how rationalized activities are adopted by organizations (Scott, 2001). Institutional theory is the traditional approach that is used to examine elements of public procurement (Obanda, 2010). Scott (2004) identifies three pillars of institutions as regulatory, normative and cultural-cognitive. The regulatory pillar emphasizes the use of rules, laws and sanctions as enforcement mechanisms, with expedience as the basis for compliance. The normative pillar refers to norms and values with social obligation as the basis of compliance. The cultural-cognitive pillar rests on shared understanding, common beliefs and symbols.

De Boer and Telgen (1998) observed that another cause of non-compliance is lack of professionalism. The PPDA Audit Report (2008) revealed that lack of professionalism was high amongst public Procurement Officers in Uganda and this can still be attributed to the fact that the profession is still young in the country. This position is confirmed by Basheka and Mugabira (2008) who state that the level of professionalism in public procurement is low or non-existent. Dobler and Burt (1996) define a profession as a calling requiring specialized knowledge and often long and intense preparation including instruction in skills and methods, maintaining by force of organization or concerted opinion high standards of achievement and conduct, and committing its members to continued study and to a kind of work which has for its prime purpose the rendering of a public service.

This definition is echoed by Millerson (1964) as cited in (Eyaa \& Oluka, 2011) who lists the following essential features of a profession. A profession according to Millerson has the following essential features: a skill based on theoretical knowledge; a skill requiring training and education; the demonstration of competence by professional by passing a test; maintenance of integrity by adherence to a code of conduct; service provided for the public good and that the profession is organized. The researcher sought to establish 
whether the staff handling procurements in the tertiary institutions in the West Nile Sub-Region were professionals in the sense described by Millerson (1964), whereby they had skill based on theoretical knowledge; a skill requiring training and education; the demonstration of competence by professional by passing a test; maintenance of integrity by adherence to a code of conduct; service provided for the public good and that the profession is organized. This study was, through its findings, to establish the fact.

Procurement professionals need to acknowledge and devise strategies for managing all these complex challenges. The professionals must be seen as champions of efficiency and effectiveness and must acknowledge the challenges and their various forms, and their sources. The requirements to educate professionals and equip them with new and higher-level skills have consequently become urgent (Sauber et al, 2008). A skill is the ability either to perform some specific behavioural task or the ability to perform some specific cognitive process that is related to some particular task (Peterson and Van Fleet, 2004). However, Lan, Riley and Cayer (2005) reported that finding, hiring and retaining dedicated, energetic, and ethical employees with special skills is always hard. While we understand that professionalism is a key mechanism for, and primary target of institutional change, the precise role of professions and professional service firms in processes of institutional change remain under-theorized (Hwang \& Powell, 2009; Scott, 2008).

Considerable attention has been given to the profile of a Procurement Officer who can demonstrate value and deliver superior performance in public procurement. The performance of procurement function in any organization requires that the individuals handling the procurement activity should have the necessary professional qualifications. A research study by Hudson (2008) has shown that in order to attain superior performance in an evolving role, Procurement Officers must have an uncommonly varied mix of both technical and behavioural competences. In addition, the Procurement Officers must identify, develop and disseminate relevant competences at the appropriate levels within the procurement hierarchy (Boyatzis, 2007; Hudson, 2008; Humphreys et al, 1998). This calls for self-efficacy to further complement procurement officers' competences and enhance procurement performance.

Bandura (as cited in Hudson, 2008) asserts that people are likely to engage in activities to the extent that they perceive themselves to be competent at those activities. This implies that Procurement Officers are more likely to attempt, to persevere, and to perform better at tasks at which they have a sense of efficacy.

Challenges, however, still exist where changes from an operational to a strategic role have not been matched with corresponding competences among Procurement Officers. In addition, failure to build self-efficacy among Procurement Officers have continued to undermine the officers' capability to learn how to cope more effectively with the increasing demand to demonstrate 
long term strategic value (Hudson, 2008). As a result, there are irregularities in the procurement process including inadequate procurement planning, poor record keeping and abuse of process such that even the highly talented Procurement Officers cannot perform their job effectively (Heslin \& Klehe, 2006; Atkinson, 2003). The truth about the same in the tertiary institution in the West Nile sub-region of Uganda were yet to be established by the study.

The diversity of the work involved in public procurement necessitates that Procurement Officers are competent in a wide variety of generic procurement skills in addition to the specific technical skills and knowledge required when procuring for different sectors and commodities. Thus, it is arguably becoming more important to identify, develop and assess the competences of Procurement Officers in public procurement to ensure that procurement activity is both compliant with legislation and obtaining value for money.

Previous studies (Ryan, Emmerling \& Spencer, 2009; Boyatzis, 2007; Spencer, 2001, 2003) have highlighted the validity and utility of competences in predicting workplace performance across a variety of settings, possibly including procurement performance. In addition, competences are a product of a job; and once generated, they link work, people and strategies for improving performance (McLagan, as cited in Boyatzis, 2007). Hudson (2008) reinforces the above studies, asserting that identifying and nurturing competences is crucial if Procurement Officers are to distinguish themselves as high performers. It was yet a question to answer if the Procurement Officers in the tertiary institutions in West Nile sub-region of Uganda identify and nurture their competences.

According to Boyatzis (2007), the theory of performance is the basis for the concept of competence. Maximum performance is believed to occur when the person's capability or competence is consistent with the needs of the job demands (roles and responsibilities) and the organizational environment, systems and structures (Boyatzis, as cited in Ryan, Emmerling \& Spencer, 2009).

Owuoth and Mwangangi (2015) showed that work professionalism has a positive effect on procurement performance in public sector in Kenya. The findings revealed that procurement performance was positively and significantly correlated with professionalism at $(\mathrm{r}=0.225, \mathrm{p}=0.008<0.05)$. This implied that professionalism has positive effects to procurement performance in public sector. These findings support the findings of Odhiambo and Kamau (2013) that the procurement system requires the input of professionals with good negotiating skills and a good grasp of market dynamics to improve procurement performance in the public sector. They argued that formalizing the professionalism of procurement capability is inextricably linked to raising the profile and credibility of procurement practice and promoting the development of a common and transferable body of knowledge (Odhiambo \& Kamau, 2013). 
Saunders (1997) believed that successful functioning of organizational structures and effective operation of planning control systems is dependent on the quality and ability of staff employed. Strategic plans should include information on the acquisition, development, use and reward of human assets. Plans need to take into account the current state of development of the procurement function and the strategic direction in which its state might change. Multi-skilling provides employees with a variety of skills and should be developed extensively. Training is beneficial and generates more than the equivalent cost in payback.

Leenders and Fearon (2002) noted that the large number of items, huge monetary volume involved, need for an audit trail, severe consequences of poor performance, and the potential contribution to effective organizational operations associated with the procurement function are five major reasons for developing a sound, professionally managed procurement system. They further argue that qualifications are crucial for value-based management which requires employees to assess and improve processes while contributing to team performance. In addition, qualifications enhance staff's ability to perform, enabling them to make better decisions, work as a team, and adapt to change, while increasing efficiency, quality, productivity and job satisfaction. Training is often for improving immediate work while education develops people for the long term. To enable individuals to create value consistently, both education and training are needed.

Cousins (2003) stressed that with the ever-increasing popularity of purchasing partnership philosophy, organizations must take a closer look at the educational levels of procurement staff. With procurement's perceived movement from a clerical service to a strategic business function, the calibre of staff in terms of training, education and skills must increase to fulfil its strategic potential. The author asserted that employees need to learn new skills for improving work performance. Procurement comprises a wide range of supply chain processes such as management of value analysis processes, supplier negotiations and quality certification; and supply market research as well as early supplier involvement in processes such as development of specifications and purchase of inbound transportation. This calls for higher professional skills for enhanced performance. In the wake of hunches that the tertiary institutions in the West Nile Sub-Region is operating in line with what Cousins (2003)advocates, only such a study would clarify it.

Baily et al (2005) propounded that knowledge of the mission, the existence of top-down objectives with related performance measures, and process guidelines to link individual or group performance to the firm's goals and expectations of upper management require good qualifications. The use of teams, cross-functional managers, broad process and linkage-oriented job responsibilities, and extensive information systems enable individuals to 
balance conflicting objectives and improve processes. Professional qualifications are the fulcrum around which performance turns. Without wellmotivated, able and well trained staff, even the more brilliantly conceived plans and strategies can fail. A motivated team whose members work for and with each other can beat a team of less motivated people even if they are greater in talent. To improve procurement performance, it is essential to understand the roles that are to be performed, the standards to be achieved and how performance is evaluated. The question to be answered here was whether the staff had professional qualifications which are the fulcrum around which performance turns; whether they were well-motivated, able and well trained staff.

According to the Scottish Government (2008), the diversity of the work involved in public procurement necessitates that Procurement Officers are competent in a wide variety of generic procurement skills in addition to the specific technical skills and knowledge required when procuring for different sectors and commodities. Thus, it is arguably becoming more important to identify, develop and assess the competences of Procurement Officers in public procurement to ensure that procurement activity is both compliant with legislation and obtains value for money.

According to Boyatzis (2007), a competence is defined as a capability, ability or an underlying characteristic of an individual which is casually related to effective or superior performance. It is a set of related but different sets of behaviour organized around an underlying construct, which we call the "intent". The behaviours are alternate manifestations of the intent, as appropriate in various situations or times. The concept of competence is used to refer to applied knowledge and skills, performance delivery, and the behaviours required to get things done very well (Armstrong \& Baron, 1995). If the procurement staff in the West Nile tertiary institutions had the necessary competencies, this study was to reveal.

According to Hutton and Moulton (2004), competences are divided into two categories, the technical or operant competences and the behavioural or personal competences. Technical competences are any technical skills which are necessary for a job role; behavioural competences are usually an expression of the softer skills involved in effective performance at a company. Technical competences are typically learned in an educational environment or on the job. On the other hand, behavioural competences like decisiveness, integrity and dealing with pressure are learned through life experiences and form our behaviour patterns. Technical competences are often seen as being more important since they are more overt and easily measured. However, Russell (2004) and Hutton and Moulton (2004) stress that behavioural competences are equally important as they constitute abilities and characteristics that help people make the most of their technical competences on the job. The study was to help 
us realize if the employees in the study scope had the behavioural competences that would, as Russell (2004) and Hutton and Moulton (2004) assert, help the employees make the most of their technical competences.

Previous studies (Ryan, Emmerling \& Spencer, 2009; Boyatzis, 2007; Spencer, 2003) have highlighted the validity and utility of competences in predicting workplace performance across a variety of settings, possibly including procurement performance. In addition, competences are a product of a job and once generated, they link work, people and strategies to improve performance (McLagan, 1997). Hudson (2008) reinforces the above studies; asserting that identifying and nurturing competences is crucial if Procurement Officers are to distinguish themselves as high performers.

Bergenhenegouwen, Horn and Mooijman (1996) argued that in a work context, individuals must possess a range of personal competences along with task-specific competences to perform effectively. Many organizations therefore combine both personal competences and job-based competences. In this regard, Russell (2004) stresses that although most models do not necessarily balance these two differing aspects effectively, success in a role depends on the ability to effectively match the technical competences of the role with its required behavioural competences. Against this background, the professionalism and competences of Procurement Officers in tertiary institutions in the West Nile sub-region of Uganda were questionable until this study proved it otherwise.

\section{$3 \quad$ Methodology}

The study was conducted following a cross-sectional survey design. The population included the institutions' Accounting Officers and members of Contracts Committees, Procurement and Disposal Units (PDU), and user departments (Table 1).

Table 1: Sample Size and Selection Techniques

\begin{tabular}{llllll}
\hline Categories & UCC Pakwach & NTC & Target Population & Sample* & Technique \\
\hline Accounting Officer & 1 & 1 & 2 & 2 & Purposive \\
Contracts Committee & 5 & 5 & 10 & 10 & Purposive \\
User department & 59 & 94 & 153 & 110 & $\begin{array}{l}\text { Simple } \\
\text { random }\end{array}$ \\
Total & 65 & 100 & 165 & 122 & \\
\hline
\end{tabular}

Source: Institutions' Departments of Human Resource (2015). *Krejcie and Morgan (1970)

A questionnaire with standardized questions was used to elicit data from the user departments. Questionnaire survey was used for this category of respondents to save on time because their number was too big to interview. Interviews were used to collect data from Accounting Officers and Contracts 
Committee members. The validity of the instrument was established at .856 by computing the content validity index using the expert ratings shown in Table 2.

Table 2: Validity of Questionnaire

\begin{tabular}{llll}
\hline Raters & Items rated relevant & Items rated not relevant & Total \\
\hline Rater 1 & 43 & 9 & 52 \\
Rater 2 & 46 & 6 & 52 \\
Total & 89 & 15 & 104 \\
\hline
\end{tabular}

The Cronbach's Alpha coefficients for the consistence of the instrument are shown in Table 3.

Table 3: Reliability of questionnaire

\begin{tabular}{lll}
\hline Variables & Cronbach's Alpha & N of Items \\
\hline Reliability for legal environment & .717 & 10 \\
Reliability for institutional human capacity & .763 & 10 \\
Reliability for institutional culture & .845 & 6 \\
Reliability for institutional politics & .805 & 6 \\
Reliability for institutional ethic values & .914 & 10 \\
Reliability for procurement performance & .745 & 10 \\
\hline
\end{tabular}

Data was analysed using frequencies, percentages and Spearman Rank Order Correlation. The frequencies and percentages were used to determine the respondents' views on institutional human capacity and procurement performance. On the other hand, Spearman correlation was used to determine the relationship between the variables. The coefficient of determination was computed and expressed as a percentage to determine the variance in procurement performance due to institutional human capacity. The data elicited from the interviewees was analysed using content analysis.

\section{$4 \quad$ Findings}

Table 4 shows that the response rate was $76 \%$, which is acceptable as representative of the respondents that were targeted (Amin, 2005; Mugenda \& Mugenda, 1999).

Table 4: Response rate

\begin{tabular}{lllll}
\hline Category of population & Population & Sample & Response Rate & Percentage \\
\hline The Accounting Officer & 2 & 2 & 2 & 100 \\
The Contracts Committee & 10 & 10 & 10 & 100 \\
User department staff & 153 & 110 & 81 & 74 \\
Total & 165 & 122 & 93 & 76 \\
\hline
\end{tabular}




\subsection{Human Capacity}

The findings on the institutions' human capacity are shown in Table 5 .

Table 5: Institutional Human Capacity

\begin{tabular}{|c|c|c|c|c|c|c|}
\hline Institutional Human Capacity & SD & $\bar{D}$ & NS & $\mathbf{A}$ & SA & Total \\
\hline \multirow[t]{2}{*}{ There is low level of professionalism in public procurement } & $\overline{9}$ & 19 & 13 & 25 & 15 & 81 \\
\hline & $-11 \%$ & $-23 \%$ & $-16 \%$ & $-31 \%$ & $-19 \%$ & $-100 \%$ \\
\hline \multirow{2}{*}{$\begin{array}{l}\text { Finding, hiring and retaining dedicated, energetic, and ethical employees with special skills in our } \\
\text { institution is always hard }\end{array}$} & 7 & 17 & 19 & 25 & 13 & 81 \\
\hline & $-9 \%$ & $-21 \%$ & $-23 \%$ & $-31 \%$ & $-16 \%$ & $0 \%$ \\
\hline \multirow{2}{*}{$\begin{array}{l}\text { Procurement Officers in our institution have an uncommonly varied mix of both technical and } \\
\text { behavioural competencies }\end{array}$} & 7 & 9 & 25 & 32 & 8 & 81 \\
\hline & $-9 \%$ & $-11 \%$ & $-31 \%$ & $-40 \%$ & $-10 \%$ & $-100 \%$ \\
\hline \multirow{4}{*}{$\begin{array}{l}\text { Procurement Officers in our institution develop and disseminate relevant competencies at the } \\
\text { appropriate levels within the procurement hierarchy } \\
\text { In adequate procurement planning, poor record keeping and abuse of process do not enable } \\
\text { highly talented Procurement Officers to perform their job effectively }\end{array}$} & 8 & 18 & 17 & 27 & 11 & 81 \\
\hline & $-10 \%$ & $-22 \%$ & $-21 \%$ & $-33 \%$ & $-14 \%$ & $-100 \%$ \\
\hline & 8 & 18 & 15 & 30 & 10 & 81 \\
\hline & $-10 \%$ & $-22 \%$ & $-19 \%$ & $-37 \%$ & $-12 \%$ & $-100 \%$ \\
\hline \multirow{2}{*}{$\begin{array}{l}\text { Procurement Officers are competent in a wide variety of generic procurement skills in addition to } \\
\text { the specific knowledge required when procuring for different departments and commodities }\end{array}$} & 3 & 15 & 26 & 27 & 10 & \\
\hline & $-4 \%$ & $-19 \%$ & $-32 \%$ & $-33 \%$ & $-12 \%$ & \\
\hline \multirow{2}{*}{$\begin{array}{l}\text { Our procurement professionals have poor negotiation skills and a poor grasp of market dynamics } \\
\text { to improve of procurement }\end{array}$} & 5 & 15 & 25 & 25 & 11 & 81 \\
\hline & $-6 \%$ & $-19 \%$ & $-31 \%$ & $-31 \%$ & $-14 \%$ & $-100 \%$ \\
\hline \multirow{4}{*}{$\begin{array}{l}\text { In our institution the staff handling the procurement activity have the necessary professional } \\
\text { qualifications } \\
\text { In our institute, we lack a motivated team whose members work for and with each. }\end{array}$} & 5 & 16 & 14 & 27 & 19 & 81 \\
\hline & $-6 \%$ & $-20 \%$ & $-17 \%$ & $-33 \%$ & $-23 \%$ & $-100 \%$ \\
\hline & 11 & 14 & 15 & 33 & 8 & 81 \\
\hline & $-14 \%$ & $-17 \%$ & $-19 \%$ & $-41 \%$ & $-10 \%$ & \\
\hline \multirow{2}{*}{$\begin{array}{l}\text { Our procurement professionals do not understand some of the roles that are to be performed, } \\
\text { the standards to be achieved and evaluation of performance }\end{array}$} & 3 & & & 32 & & \\
\hline & $-4 \%$ & $-14 \%$ & $-23 \%$ & $-40 \%$ & $-20 \%$ & $-100 \%$ \\
\hline
\end{tabular}
KEY: SD = Strongly Disagree; D = Disagree; A = Agree; SA = Strongly Agree. 
The findings in Table 5 show that most user department staff members concurred to all items about institutional human capacity (that is items 1 to 10) compared to those who opposed or were not sure. A comparison on these items shows that those that opposed ranged from $18 \%$ to $34 \%$ while those that were not sure ranged from $16 \%$ to $32 \%$ and those that concurred ranged from $45 \%$ to $60 \%$. From these comparisons, it can be seen that the percentages of those that opposed the items and those who were not sure were lower compared to those who concurred. From this analysis, the following is the interpretation. Findings show most user department staff members were of the view that there was low level of professionalism in public procurement; hiring and retaining dedicated, energetic and ethical employees with special skills was always hard; and Procurement Officers had an uncommonly varied mix of both technical and behavioural competences. Most user department staff members were of the view that Procurement Officers developed and disseminated relevant competences at the appropriate levels within the procurement hierarchy, inadequate procurement planning, poor record keeping and abuse of process did not enable highly talented Procurement Officers to perform their job effectively; and Procurement Officers were competent in a wide variety of generic procurement skills in addition to the specific technical skills and knowledge required when procuring for different departments and commodities. Most user department staff members were of the view that procurement professionals had poor negotiation skills and a poor grasp of market dynamics to improve on procurement; staff handling the procurement activity had the necessary professional qualifications; the institutes lacked a motivated team whose members work for and with each other; and procurement professionals did not understand some of the roles that were to be performed, the standards to be achieved and evaluation of performance.

Interview findings from key informants support the above findings and shed more light on institutional human capacity of tertiary institutions. During interviews with key informants, the low institutional human capacity in terms of professionalism and competences was emphasized as shown in the following responses from UCC key informant A and NTC key informant W:

The professional are few and thus professionalism would not work. Labour is very mobile and they go where there is good pay. Professional ethic and code of conduct are, not followed in spite of filling the ethical forms and signing it every time. The relevant information is hidden and only expired information is availed for the consumption of others (Interview with UCC Key Informant A, $8^{\text {th }}$ May 2017).

There is low level of professionalism in public procurement in some institutions but not all. During hiring and retaining, many things are considered such as some tribes are not trusted, the kind of friendship you 
have with the stakeholders and how compliant you will be to your bosses. Procurement Officers in our institution do not develop and disseminate relevant competences at the appropriate levels within the procurement hierarchy (Interview with NTC Key Informant W, $9^{\text {th }}$ May 2017).

The UCC Key Informant B had this to say, "In the areas of technical competencies we would hire some knowledgeable people to come and help us whenever there were big procurement" (Interview with UCC Key Informant B, $10^{\text {th }}$ May 2017). Similarly, the NTC Key Informant X was of the following view, "The procurement department does not have real qualified professionals or certified professionals" (Interview with NTC Key Informant X, $11^{\text {th }}$ May 2017).The UCC Key Informant $C$ revealed the following, "None of the staff did a full course on procurement and some are in those positions because they have some kind of relationship with the accounting officer" (Interview with UCC Key Informant C, 12 $2^{\text {th }}$ May 2017). From the findings, it is shown that the institutional human capacity in tertiary institutions is characterized by low levels of professionalism and a lack of competences required for execution of their duties. Motivation and knowledge about roles that are to be performed, the standards to be achieved and evaluation of performance also compromised the tertiary institutional human capacity as revealed by the UCC Key Informant A and the NTC Key Informant Y in the following:

Employees are only motivated when they know there would be a difference or kick back for their benefit. The accounting officer would guide the procurement department on what to do yet he was not a professional

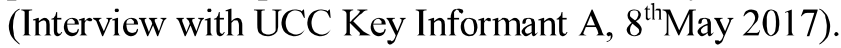

Motivation of employees is not right in our institution. In most cases, all issues to be handled are predetermined by the accounting officer; meetings are for formalities. Knowledge about roles that are to be performed, the standards to be achieved and evaluation of performance is limited because even the right procedures are never followed (Interview with NTC Key Informant $\mathrm{Y}, 13^{\text {th }}$ May 2017).

Thus, both findings obtained using questionnaires and interview guides revealed that the tertiary institutional human capacity was wanting. Poor tertiary institutional human capacity can lead to poor procurement performance.

\subsection{Procurement Performance}

User department staff members responded to 10 items about procurement performance in tertiary institutions in the West Nile sub-region of Uganda by 
indicating their agreement using a five-point Likert scale as shown in Table 6. The analysis and interpretation of the findings follows the presentation.

Table 5: Procurement Performance

\begin{tabular}{|c|c|c|c|c|c|c|}
\hline Procurement Performance & SD & $\mathrm{D}$ & NS & A & SA & Total \\
\hline $\begin{array}{l}\text { Competitive prices are not paid for focus } \\
\text { products. }\end{array}$ & $\begin{array}{l}5 \\
(6 \%)\end{array}$ & $\begin{array}{l}11 \\
(14 \%)\end{array}$ & $\begin{array}{l}31 \\
(38 \%)\end{array}$ & $\begin{array}{l}27 \\
(33 \%)\end{array}$ & $\begin{array}{l}7 \\
(9 \%)\end{array}$ & $\begin{array}{l}81 \\
(100 \%)\end{array}$ \\
\hline $\begin{array}{l}\text { Inefficient procurement mechanisms are } \\
\text { being used. }\end{array}$ & $\begin{array}{l}8 \\
(10 \%)\end{array}$ & $\begin{array}{l}13 \\
(16 \%)\end{array}$ & $\begin{array}{l}18 \\
(22 \%)\end{array}$ & $\begin{array}{l}35 \\
(43 \%)\end{array}$ & $\begin{array}{l}7 \\
(9 \%)\end{array}$ & $\begin{array}{l}81 \\
(100 \%)\end{array}$ \\
\hline $\begin{array}{l}\text { Suppliers do not deliver the right goods } \\
\text { at the right time. }\end{array}$ & $\begin{array}{l}6 \\
(7 \%)\end{array}$ & $\begin{array}{l}20 \\
(25 \%)\end{array}$ & $\begin{array}{l}17 \\
(21 \%)\end{array}$ & $\begin{array}{l}29 \\
(36 \%)\end{array}$ & $\begin{array}{l}9 \\
(11 \%)\end{array}$ & $\begin{array}{l}81 \\
(100 \%)\end{array}$ \\
\hline $\begin{array}{l}\text { There are delays in the procurement } \\
\text { cycle. }\end{array}$ & $\begin{array}{l}1 \\
(1 \%)\end{array}$ & $\begin{array}{l}11 \\
(14 \%)\end{array}$ & $\begin{array}{l}21 \\
(26 \%)\end{array}$ & $\begin{array}{l}33 \\
(41 \%)\end{array}$ & $\begin{array}{l}15 \\
(19 \%)\end{array}$ & $\begin{array}{l}81 \\
(100 \%)\end{array}$ \\
\hline There are delays in processing payments. & $\begin{array}{l}5 \\
(6 \%)\end{array}$ & $\begin{array}{l}6 \\
(7 \%)\end{array}$ & $\begin{array}{l}24 \\
(30 \%)\end{array}$ & $\begin{array}{l}28 \\
(35 \%)\end{array}$ & $\begin{array}{l}18 \\
(22 \%)\end{array}$ & $\begin{array}{l}81 \\
(100 \%)\end{array}$ \\
\hline $\begin{array}{l}\text { There are emergency orders frequently } \\
\text { used to prevent stock-outs. }\end{array}$ & $\begin{array}{l}5 \\
(6 \%)\end{array}$ & $\begin{array}{l}11 \\
(14 \%)\end{array}$ & $\begin{array}{l}35 \\
(43 \%)\end{array}$ & $\begin{array}{l}23 \\
(28 \%)\end{array}$ & $\begin{array}{l}7 \\
(9 \%)\end{array}$ & $\begin{array}{l}81 \\
(100 \%)\end{array}$ \\
\hline $\begin{array}{l}\text { The procurement unit is operating } \\
\text { inefficiently. }\end{array}$ & $\begin{array}{l}6 \\
(7 \%)\end{array}$ & $\begin{array}{l}19 \\
(23 \%)\end{array}$ & $\begin{array}{l}19 \\
(23 \%)\end{array}$ & $\begin{array}{l}28 \\
(35 \%)\end{array}$ & $\begin{array}{l}9 \\
(11 \%)\end{array}$ & $\begin{array}{l}81 \\
(100 \%)\end{array}$ \\
\hline $\begin{array}{l}\text { Funded operational training program is } \\
\text { not in place to provide staff with } \\
\text { procurement training }\end{array}$ & $\begin{array}{l}11 \\
(14 \%)\end{array}$ & $\begin{array}{l}18 \\
(22 \%)\end{array}$ & $\begin{array}{l}18 \\
(22 \%)\end{array}$ & $\begin{array}{l}29 \\
(36 \%)\end{array}$ & $\begin{array}{l}5 \\
(6 \%)\end{array}$ & $\begin{array}{l}81 \\
(100 \%)\end{array}$ \\
\hline $\begin{array}{l}\text { Procurement prices are not available to } \\
\text { the public. }\end{array}$ & $\begin{array}{l}10 \\
(12 \%)\end{array}$ & $\begin{array}{l}16 \\
(20 \%)\end{array}$ & $\begin{array}{l}31 \\
(38 \%)\end{array}$ & $\begin{array}{l}20 \\
(25 \%)\end{array}$ & $\begin{array}{l}4 \\
(5 \%)\end{array}$ & $\begin{array}{l}81 \\
(100 \%)\end{array}$ \\
\hline $\begin{array}{l}\text { Procurement methods being used do not } \\
\text { promote competition. }\end{array}$ & $\begin{array}{l}8 \\
(10 \%)\end{array}$ & $\begin{array}{l}10 \\
(12 \%)\end{array}$ & $\begin{array}{l}17 \\
(21 \%)\end{array}$ & $\begin{array}{l}36 \\
(44 \%)\end{array}$ & $\begin{array}{l}10 \\
(12 \%)\end{array}$ & $\begin{array}{l}81 \\
(100 \%)\end{array}$ \\
\hline
\end{tabular}

Findings show that most of the user department staff members concurred with eight items about procurement performance (that is items 1, 2, 3, 4, 5, 7, 8 and 10) compared to those who opposed and were not sure. A comparison on these items shows that those that opposed ranged from $13 \%$ to $36 \%$ while those that were not sure ranged from $21 \%$ to $38 \%$ and those that concurred ranged from $42 \%$ to $60 \%$. From these comparisons, it can be seen that the percentages that concurred with the items were higher compared to those who were not sure and those that opposed. From this analysis, the following is the interpretation. Findings show most user department staff members were of the view that competitive prices were not paid for focus products; inefficient procurement mechanisms were used; suppliers did not deliver the right goods at the right time; and, there were delays in the procurement cycle and in processing payments. Furthermore, most user department staff members were of the view that the procurement unit was operating inefficiently; funded operational training programme was not in place to provide staff with appropriate training 
to maintain or upgrade their procurement skills; and procurement methods used did not promote competition.

On the other hand, findings show that most of the user department staff members were not sure regarding two items about procurement performance (that is items 6 and 9) compared to those who concurred and those who opposed. A comparison of these items shows that those that opposed ranged from $20 \%$ to $32 \%$, while those that were not sure ranged from $38 \%$ to $43 \%$ and those that concurred ranged from $30 \%$ to $37 \%$. From these comparisons, it can be seen that the percentages that were not sure about the items were higher compared to those who were opposed and those who concurred. From this analysis, the following is the interpretation. Findings show most user department staff members were of the view that they were not sure whether emergency orders were frequently used to prevent stock-outs or procurement prices were not available to the public.

Therefore, these findings show poor procurement performance in tertiary institutions in the West Nile sub-region of Uganda. Having established the views of user department staff members on procurement performance, the following subsection presents findings linking institutional human capacity and procurement performance.

\subsection{Institutional Human Capacity and Procurement Performance}

The second hypothesis, "Institutional human capacity significantly affects the performance of procurement in different tertiary institutions in West Nile subregion of Uganda" was tested using Spearman rank order correlation test and the coefficient of determination. The results are shown in Table 7.

Table 7: Institutional Human Capacity and Procurement Performance

\begin{tabular}{ll}
\hline & Institutional human capacity \\
\hline Procurement performance & $r h o=.611$ \\
& $r h o^{2}=.373$ \\
& $\mathrm{p}=.000$ \\
$\mathrm{n}=81$
\end{tabular}

The findings in Table 7 show that there was a strong positive correlation $(r h o=$ .611) between institutional human capacity and procurement performance in tertiary institutions in the West Nile sub-region of Uganda. The coefficient of determination $\left(r h o^{2}=.373\right)$ shows that institutional human capacity accounted for $37.3 \%$ variance in procurement performance. These findings were subjected to a test of significance ( $p$ ) and it is shown that the significance of the correlation $(\mathrm{p}=.000)$ is less than the recommended critical significance at .05 . Because of this, the hypothesis "Institutional human capacity significantly 
affects the performance of procurement in different tertiary institutions in West Nile sub-region of Uganda" was accepted.

The implication of the findings was linear in nature; that is, the stronger effect implied that a change in institutional human capacity contributed to a big change in procurement performance in tertiary institutions in the West Nile sub-region of Uganda. The positive nature of the effect implied that the change in institutional human capacity and procurement performance in tertiary institutions in the West Nile sub-region of Uganda was in the same direction, whereby better institutional human capacity contributed to better procurement performance in tertiary institutions, while poor institutional human capacity contributed to poor procurement performance in tertiary institutions in the West Nile sub-region of Uganda.

\section{Discussion, Conclusion and Recommendation}

The study sought to determine the effect of institutional human capacity on procurement performance in tertiary institutions in the West Nile sub-region of Uganda. The study established a strong positive correlation between institutional human capacity and procurement performance in tertiary institutions in West Nile sub-region of Uganda. Monitoring and enforcement of quality standards is sometimes weak and the failure can be traced back to problems in human resource capacity to monitor the procurement process. Regulatory agencies rarely manage to enforce standards due to lack of capacity (Banda, 2009).

This study established that tertiary institution procurement professionals had poor negotiation skills; poor grasp of market dynamics to improve on procurement; the institutes lacked motivated teams; and procurement professionals did not understand some of the roles that were to be performed, the standards to be achieved and evaluation of performance. These findings concur with Appiah (2010) who observed that the human capital competence influences the implementation of the public procurement procedures in diverse ways. These ways include the possession of technical skills of the procurement officials; knowledge of the procurement procedures; possession of sufficient professional experience; formal educational background; and the provision of the necessary orientation among staff. All these go a long way to explain the low procurement performance.

In the context of the examined human capital competence, the possession of the requisite technical skills and the provision of the foundational skills affect the procurement procedures and practices (Sultana, 2012). The technical skills are critical in the Procurement Officers being able to adhere to the procurement procedures and practices despite the challenges or complexity involved in the 
procurement process (Frooman, 1999). On the other hand, the ability of the organizations to give foundational skills to the Procurement Officers gives them awareness on what is expected of them (Sultana, 2012). Both quantitative and qualitative results, however, have established that the staff were not well qualified in the area of public procurement. Given that both technical and behavioural qualifications are a prerequisite for efficiency and effectiveness, it is no wonder that there is low procurement performance in public performance in the tertiary institutions in the West Nile sub-region of Uganda.

This study established that most procurement personnel had the required knowledge in procurement. The performance of procurement function in any organization requires that the individuals handling the procurement activity should have the necessary professional qualifications (Abdulai \& Birachi, 2009). This study established that employees' experience, professional qualification, skills and level of education influences the procurement performance in tertiary institutions in the West Nile sub-region of Uganda. On the other hand, lack of motivation which is critical to good performance of employees could explain the low performance in procurement, since the study findings revealed staff motivation to be at a low level.

Finding of this study are supported by literature that has highlighted that human capacity in procurement performance is of importance. According to Banda (2009), many procuring organizations do not have staff with the right competence critical to good procurement process management. His study notes that there is need for authorities to give much greater emphasis to developing such competence and to adopt best practice more widely. A procurement function that is carried out professionally is the heart of delivery of any service on value for money principle. The findings of this study are similar to another study where it was noted that most of personnel carrying out procurement functions in the local authorities in Kenya had not been sensitized on procurement regulations. In emphasis, the law requires that each procuring entity establishes a procurement unit with the professionals. This was not the case in 15 out of 27 surveyed local authorities in Kenya.

According to the report, it was observed that there were serious challenges in staffing of procurement professionals in the local government institutions, which was similar to the tertiary institutions in the West Nile sub-region of Uganda. Some of the personnel carrying out those duties do not have any certification in procurement and most have never been sensitized and have little knowledge, if any, of the procurement function. In order to sustain effective procurement performance, it is important to optimize the contribution of employees to the aims and goals of the organizations (Frooman, 1999). Technological developments and organizational change have gradually led some employers to the realization that success relies on the skills and abilities of their employees, and this means considerable and continuous investment in 
training and development (Sultana, 2012). There is therefore the need for extensive external training for human resources to be able to improve and contribute to the productivity of organizations (Appiah, 2010). The study further revealed that there are clear benefits in ensuring that employees who handle suppliers are professionals and approaches are handled well. Competence can ensure that the benefits of new products and services are brought to the attention of the right person in the organization. It can protect the organization, keep work to a minimum, avoid souring relationships and add to the organization's reputation for efficiency and good management. The study noted that in procurement, it is not what you do but how you do it that matters. The researcher, however, observes that both are important since the how does not arise at all without the what, of procurement.

The study concludes that institutional human capacity has a moderate positive effect on procurement performance in tertiary institutions in the West Nile sub-region of Uganda. The study found that a unit increase in institutional human capacity will lead to a $37.3 \%$ increase in procurement performance in tertiary institutions in the West Nile sub-region of Uganda. The study established that employees' experience, professional qualification, skills and level of education influence the procurement performance in tertiary institutions in the West Nile sub-region of Uganda.

In the context of the human capital competence, the study recommends that the tertiary institutions in the West Nile sub-region of Uganda should pay keen attention to the technical skills of their procurement officials through recruitment, professional exposure in conferences and seminars, and in-house training. This will enable the tertiary institutions to be better equipped to execute prudent procurement procedures and practices.

\section{References}

African Peer Review Mechanism Country Review (APRM, 2009). Republic of Uganda. APRM Country Review Report, No. 7.

Agaba, E. \& Shipman, N. (2006) Public Procurement Reform in Developing Countries: The Ugandan Experience. In G. Piga \& K. V. Thai (Eds.), Advancing Public Procurement: Practices, Innovation and KnowledgeSharing, pp. 373-391, USA: Pr Academics Press.

Amin, M. E. (2005). Social Science Research Methods: Conception, Methodology and Analysis, Makerere University Printery, Kampala.

Armstrong, M. \& Baron, A. (1995). The Job Evaluation Handbook. London: Institute of Personnel Development.

Arrowsmith, S. \& Trybus, M. (2003). Public Procurement: The Continuing Revolution. Kluwer Law International. 
Atkinson, W. (2003). New buying tools present different ethical challenges. Purchasing, 132 (4), 27-30.

Basheka, B. C. \& Mugabira, M. I. (2008). Measuring Professionalism Variables and their Implication to Procurement Outcomes in Uganda. The $3^{\text {rd }}$ International Public Procurement Conference Proceedings.

Bergenhenegouwen, G., Horn, H. and Mooijman E. (1996). Competence development-a Challenge for HRM professionals: core competences of organizations as guidelines for the development of employees. Journal of European Industrial Training, 29 (9), 29-35.

Bixby, M., Beck-Dudley, C. \& Cihon, P. (2008). The Legal Environment of Business, 4th ed. Hudson in New York City, New York: Pearson Custom Publishing.

Boyatzis, R. E. (2007), Competencies in the 21st Century. Journal of Management Development, 27 (1), 5-12.

Brown, T. L., Potoski, M. \& Van Slyke, D. M. (2006). Managing Public Service Contracts: Aligning Values, Institutions, and Markets, Public Administration Review, 66:3 pp. 323-331.

Chan, J. K. C. \& Lee, M. K. O. (2003). SME e-procurement adoption in Hong Kong - The roles of power, trust and value. IEEE Computer Society. Proceedings 36th Hawaii International Conference on System Sciences. 110.

CIPS Australia. (2005). How do we measure up? An Introduction to Performance Measurement of the Procurement Profession. Retrieved 19 May 2015 from http://www.cips.org/ documents/Performance_Measurement.pdf

Cousins, P. D. (2003). Strategic supply and the management of inter-and intraorganizational relationships. Journal of Purchasing \& Supply Management, Vol. 9 No. 1, pp. 19-29.

De Boer, L., \& Telgen, J. (2006), Purchasing Practice in Dutch Municipalities, Journal of Supply Chain Management, Vol. 34, No. 2, 31-36.

Dunn, M. B., \& Jones, C. (2010). Institutional logics and institutional pluralism: The contestation of care and science logics in medical education 1967-2005. Administrative Science Quarterly, 55, 114-149.

Eyaa, S. \& Oluka, P. N. (2011). Explaining non- compliance in public procurement in Uganda. International Journal of Business and Social Science, Vol. 2, No. 11, 35-44.

Gelderman, C. J., Ghijsen, P. W., \& Brugman, M. J. (2006). Public procurement and EU tendering directives - explaining non-compliance. International Journal of Public Sector Management, 19(7): 702-714.

Heslin, P. A., \& Klehe, U. C (2006). Self-efficacy. In S. G. Rogelberg (Ed.), Encyclopaedia of Industrial / Organizational Psychology, pp. 705-708. Thousand Oaks: Sage. 
Hudson. (2008). Procurement Leaders in a changing world: will they decline or thrive? Hudson

Hughes, M. (2005). Evaluation of the Local Government Procurement Agenda - Baseline Survey Report. The Office of the Deputy Prime Minister, London.

Hutton, D. \& Moulton, S. (2004) Behavioural Competencies for Health Care Leaders.

Retrievedfromhttp://www.hhnmag.com/hhnmag_app/jsp/articledisplay.jsp?d crpath=HHNMAG/PubsNewsArticle/data/041005HHN_Online_Hutton\&do main $=$ HHNMAG.

Hwang, H. \& Powell, W. W. (2009). The Rationalization of Charity: The influences of professionalism in the non-profit sector. Administrative Science Quarterly, 54(2): 268-298.

Kettl, D. (1993). Sharing Power: Public Governance and Private Markets. Washington D.C.: The Brookings Institution.

Krejcie, R. and Morgan, D W. (1970). Determining Sample Size for Research Activities, Educational and Psychological Measurement. London: Sage Publications.

Lan, Z.G. Riley, L. \& Cayer, J. N. (2005). How can local Government Become and Employer of Choice for Technical professionals? Review of Public Administration, Vol. 25, No. 3, 225-242.

Lardenoije, E. J., Van Raaij, E. M. \& Van Weele, A. J. (2005). Performance Management Models and Purchasing: Relevance Still Lost. Researches in Purchasing and Supply Management, the $14^{\text {th }}$ IPSERA Conference, pp. 68797. Archamps.

Leenders, R. M. \& Fearon, E. H. (2002). Purchasing and Supply Management, $12^{\text {th }}$ ed. Chicago: McGraw-Hill Companies.

Lisa, I. (2010). Compliance culture. A conceptual framework. Journal of management organization, 19(7), 702-714

McLagan, P.A. (1997). Competencies: the next generation. Training and Development, 55 (5), 40.

Mugenda, O. M. \& Mugenda, A. G. (1999). Research methods Qualitative and Quantitative Approaches. Nairobi: African Centre for technology Studies (ACTS).

North, Douglas (1991). Institutions, Journal of Economic Perspectives, 5, Winter, pp.97-112.

Ntayi, J. M. (2009). Instrumental ethical climate, psychological wellness and task performance E-Journal of Business and Economic, Issues Issue 1 Volume 4.

Odhiambo, W., \& Kamau, P. (2013). Public Procurement: Lessons from Kenya, Tanzania and Uganda. OECD Working Paper NO. 208. OECD Development Centre. Retrieved from: http/www.wto.org, on 15th Dec. 2009. 
Owuoth, G. G. \& Mwangangi, P. (2015). Effect of public procurement regulations on procurement performance in public sector in Kenya: A case of Rural Electrification Authority. International Journal of Social Sciences Management and Entrepreneurship, 2(1):171-184 March/May 2015.

PPDA Act (2003). Public Procurement and Disposal of Public Assets, Republic of Uganda.

PPDA. (2007). Discussion Paper on Amendment to the Act. Kampala: PPDA Authority.

Public Procurement and Disposal of Public Assets Authority (2009). Procurement and Disposal Audit Report of Makerere University for Financial Year 2008/2009. Kampala: Public Procurement and Disposal of Public Assets Authority

Public Procurement and Disposal of Public Assets Authority (2010). Procurement and Disposal Audit Report of Mbarara University for Financial Year 2008/2009. Kampala: Public Procurement and Disposal of Public Assets Authority

Public Procurement and Disposal of Public Assets Authority (2011). Procurement and Disposal Audit Report of Gulu University for Financial Year 2009/2010. Kampala: Public Procurement and Disposal of Public Assets Authority

Public Procurement and Disposal of Public Assets Authority (2014). Procurement and Disposal Audit Report of Kyambogo University for Financial Year 2013/2014. Kampala: Public Procurement and Disposal of Public Assets Authority

Russell, I. (2004). People Management and Competency Profiling. South Yarra, Australia: Test Grid Pty Ltd.

Ryan, G., Emmerling, R. J. \& Spencer, L. M. (2009). Distinguishing highperforming European executives: The role of emotional, social and cognitive competencies. Journal of Management Development, 28 (9), 859-875.

Sauber, M. H. et al (2008). Developing supply chain management program: a competency model, Quality assurance in Education, Vol. 16, No. 4, 375- 
Scott, W. R. (2008). Institutions and Organizations - Ideas and Interests, $3^{\text {rd }}$ ed. Foundations for Organizational Science Series, SAGE Publications, Thousand Oaks, CA.

Spencer, L. M. (2003). How competencies create economic value. In L. A. Berger \& D. R. Berger (Eds.). The Talent Management Handbook: Creating Organizational Excellence by Identifying, Developing, and Promoting Your Best People (pp. 64-84). New York, NY: McGraw-Hill.

Thai, K. V. (2005). Challenges in Public Procurement. In Thai, K. V. et al. (Eds.), Challenges in Public Procurement: An International Perspective (pp. 1-20). Boca Raton, Florida, USA:

Van Weele, A. J. (2006). Purchasing \& Supply Chain Management: Analysis, Strategy, Planning and Practice, $4^{\text {th }}$ ed. Australia: Thomson.

Victor A. (2012). Challenges affecting procurement practices in public corporations. International Journal of Operations \& Production Management, Vol. 31.

World Bank. (2010). World Development Report 2007: Development and the Next Generation. New York. 